\title{
The Refusal of Performing Bad Deeds by God in Shiite School
}

\author{
Akbar Faydei \\ Lecturer, Department of Islamic Philosophy, Azarbaijan Shahid Madani University, Iran \\ Email: faydei@yahoo.com
}

Doi:10.5901/mjss.2016.v7n3s3p192

\begin{abstract}
The issue of absolute divine power based on believing in monotheism in the Creation as a substantial quality and God's beauty as well as its relation to divine fortuity, determinism and free will is one of the most important discussions that has occupied man's thought and has provided the background for the appearance of questions and doubts such as the existential philosophy of evil and bad deeds as well as their real doer. Therefore, throughout history theologian intellectuals have attempted to find solutions to respond to such doubts. Ash'arites who consider God as the creator of all things including man's deeds, have suggested the theory of acquirement to go out of the problem of mere determinism and justifying duty, reward and heavenly punishment. Mu'tazila have presented conferment idea and have curtailed God's power from man's deeds in order to trim divine presence from bad deeds. Shiite have considered God's presence pure from any bad deed inspired by the Koran's holy verses while believing in unlimited divine power. The present paper, while investigating different views, introduces Shiite's view in this regard and its adaptability to Koranic teachings.
\end{abstract}

Keywords: Divine Power, Good and Evil, Good Deed and Bad Deed, Determinists, Conferment, Shiite School.

\section{Introduction}

\subsection{Statement of the Problem}

We believe in the God of the universe, who is the omnipotent and benevolent one based on religious teachings. Furthermore, we are confronted with types of human and moral evil and disasters as well as bad deeds. On the one hand, bad deeds are ascribed to God in terms of their existence, because God is the real cause of all deeds, on the other hand, performing bad deed by God is inadaptable with His wisdom and justice. Therefore, important questions occur to man's mind such as "If God's is not the doer of bad deeds, so who is the origin of them? If man is the doer of bad deeds, why he has vested authority to man so much and does not prevent from his oppression and injustice?"

Does God's will appertain to the achievement of man's all voluntary deeds such as good and bad ones? How divine absolute power is justifiable with man's bad and evil deeds? Introducing and investigating Islamic theologians' views especially Shiite in response to the questions is the main discussion of the present paper.

\subsection{Good and Bad Deeds}

Good and bad mean agreeableness and disagreement with nature such as justice and oppression as well as perfection and imperfection qualities such awareness and ignorance, which is rational according to most theologians' consensus. But Adliyeh and Ash'arites have difference of opinion concerning the rationality or lawfulness of good and bad in the sense of being praiseworthy and blameworthy (Heli, 1981, 64).

Sometimes, the intention of good and bad adaptability or inadaptability to nature or perfection and imperfection qualities. In this sense, good and bad are rational, but sometimes, the intention of good and bad is that a deed results in reward and punishment or cause praise and blame. Good and bad in the later sense, contrary to Mu'tazila, are lawful not rational (Fakhrerazi, 1989, 478-479). Ash'arites believe that no deed is not good or bad by itself, but GBD (Goodness and Badness of Deeds) is a religious issue. Any work that God conduct and issue will be good and any work that God abandon and forbid bounded persons from doing it will be bad (Fakhrerazi, 1986, 346). Deed will be good and bad only by God's will (Teftazani, Undated, 282). GBD depends on divine command and prohibition. Therefore, servant cannot identify GBD and their goodness and evilness.

According to Mu'tazila, deeds are inherently good or bad and man's reason can distinguish goods works from bad ones. They believe that a number of deeds are blameworthy in the world and punishable in the afterlife and some other 
ones are praiseworthy and rewarding. However, according to Ash'arites, only religion precept can determine the praise and blame as well as reward and punishment (Abdul-Jabbar, 1960, 18).

Teftazani states that "Contrary to Mu'tazila, man's reason has no precept regarding good and bad in the sense of praise and blame before God, but there is no disagreement between us and Mu'tazila in the sense of perfection and imperfection as well as adaptability and inadaptability to nature. In our view, God's command and prohibition make deeds good and bad. However, according to Mu'tazila, good deed appertains to God's command owing to its goodness and bad deed is forbidden because of its badness so that it is said that if GBD is not extemporarily understand by reason and theory, legislator's view and precept will be revealed by the GBD not indicated by them." (Teftazani, Undated, 282).

In Ash'arites' view, the praise and blame as well as the reward and punishment of deeds depend only on religious precept, but Mu'tazila believe in the inherent and rational goodness and badness and regard rational precept involved in the praiseworthiness and blameworthiness as well as reward and punishment of deeds (Toosi, Undated, 78).

Shiite like Mu'tazila consider GBD inherent with the different that the goodness and badness of some deeds are evident such as goodness of beneficial veracity, goodness of rejecting deposit, goodness of thanking benefactor, justice and beneficence and badness of hurtful lie, oppression, foolishness and badness of duty as unbearable. But the goodness and badness of a number of deeds are inferred by theoretical reason such as goodness of beneficial veracity and badness of profitable lie. In addition, the goodness and badness of some deeds are not identified by reason such as the goodness and badness of fasting in the last day of Ramadan and the first day of Shavval and other worshipping deeds that in this case, revelation helps servants to learn what they are not able to know (Ibid). Contrary to Ash'arites, they believe that GBD is inherent and ascribing bad deeds to God is inadaptable to His wisdom and magnanimity.

Ash'arites have mentioned weak reasons to prove religious goodness and badness that they are all answered in Shiite's books. For example, Ash'arites say that if GBD are indispensable and evident, they should not be different with the initial truths such as "Each entire is bigger than its component", while the last precept is clear for all, but people have difference of opinion regarding GBD. Shiite in response to this have said that evident notions had different degrees in terms of clarity and concealment and many requirements were hidden for some people due to the lack of its notion. Furthermore, the rationality of GBD concern being evident (Heli, 1987, 236-237).

On the other hand, GBD belong to practical reason, but "الجل اعظم من الجز" is relevant to theoretical reason. Thus, this analogy of Ash'arites is an argument from analogy.

Shiite that have considered reason independent of identifying the goodness and badness of many deeds by believing in GBD. To confirm its claim, they say that if GBD was religious, it would have issued the order of the goodness of some deeds and badness of some other deeds unique to the follower of divine religions, while the deniers of divine religions issue the order of the goodness of some deeds such as helping orphans and the badness of some deeds such as bothering orphans. Moreover, if GBD is not rational, we do not issue the order of the badness of lying and it would be likely to consider that God will lie that in this case, GBD will not be proved by religion, because it would be likely to regard God's all commands and prohibitions had been untruth and divine deeds are not by wisdom (Ibid, 235-236).

\subsection{Relation between God's Absolute Power and Man's Deeds in Islamic Theologians' View}

Many theologians have guessed that a voluntary deed cannot have two independent doers. Therefore, they have considered determinism and considered all deeds even man's bad deeds as God's deed. Some other ones have regarded conferment and considered man as an independent doer in a number of his deeds, but Shiite theologians and most of Islamic philosophers believe in the theory of "between-two issue" and do not ascribe man's bad deeds to God.

\subsection{Jahmi's View}

Jahm Bin Safvan and his followers considered God as the only doer of all deeds and even appertain man's bad deeds, blasphemy and faith to only God's will (Tabari, 1996, 173-174). They have said that man was forced in all his deeds. Any deed is achieved only by God's power and will and servants have no interference in the achievement of their deed. Servants have not effective and acquiring power (Abdul-Jabbar, 2006, 324). In addition, ascribing deeds to someone but God is by way of negligence and metaphor (Lahiji, 1992, 364), because there is no authority but God.

\subsection{Criticism}

The right is that the existence of volition and free will for man is an evident and conscionable issue. 


\subsection{Mu'tazila's View}

Mu'tazila believe in conferment and the theory of conferment is contrary to the theory of determinism. Based on this theory, man's voluntary deed is only created by himself and is not created by God (Lahiij, 2004, 327). Servants are doer and the creator of their voluntary deeds including obedience and sin and God's power and free will are impossible to encompass man's voluntary deed (Fakhrerazi, 2007, 144, 184-185). God has placed identification power and doing deeds in man's free will and has ordered him to good deed and has forbidden him from bad deed and has no further interference in the achievement of man's deeds and servants' deeds are achieved by their power and free will. Therefore, God's power does not include man's voluntary deeds. If it was not so, afterlife reward and punishment were irrelevant (Tabari, 1996, 167).

Most of Mu'tazila consider man as an independent doer in some of his deeds (Eyji, 1991, 146). They say that sometime man commit evil, bad deeds and oppression, how such deeds can be ascribed to God? (Abdul-Jabbar, 2006, 345). God who is mere goodness is the origin of good things not evil ones (Shahrestani, Undated, 45). It is not allowable that eternal God commit bad deeds eternal God is aware of the badness of bad deed and has no need to do bad deed. Therefore, it is not permissible for him to choose bad deeds (Abdul-Jabbar, 2003, 16). God chooses only wisdom and good deed... servants' deeds are ascribed to themselves and are not created by God, because bad deeds are not God's intention, but God hates them and the one who commit bad deeds will be treated with anger by God (Ibid, Undated, 232).

They say that God has created man and has granted power, and independent free will to them. Thus, some man's deed are created by man himself and God has no interference in creating them. For this reason, man is deserved to afterlife reward and punishment (Abdul-Jabbar, 2006, 323, 332). God has not power on the thing that has made man able in it, because it is impossible that a deed would be feasible by two individuals (Ibid, 375).

Abu Ali Jabaie and many of Mu'tazila say that God is unable in God's possible self, but has power on the deed quality that has made man on its basis and is able to make man on the quality of his possibilities (Teftazani, 1973, 73). However, Baghdad Mu'tazila believe in mere conferment. They say that God has not power on man's possibility principle and his possible quality (Ashari, 1994, 229). Baghdad Mu'tazila's necessity is God's inability towards man's deeds. In other words, in spite of man's ability, God cannot hinder man concerning possible principle or quality.

Mu'tazila, to confirm their claim, say that servants' sins are not divine fortuity, because God has said "Someone

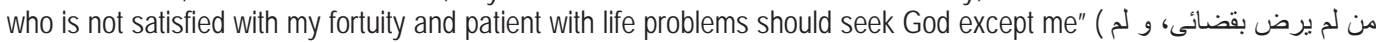

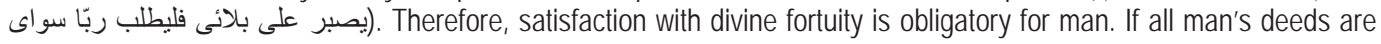
achieved by divine fortuity, it will be necessary that man be satisfied with all his deeds such as blasphemy and atheism. While, satisfaction with blasphemy negates man's faith (Abdul-Jabbar, 2006, 771). In the holy verse of " is correct that "All things" have generality, but the intention of this general utterance is all deeds, which do not belong to man's power, because ascribing man's deeds to God requires the assemblage of two doers empowered on one deed and that is impossible (Al-Juzi, Undated, 123).

Mu'tazila say that man do what he want to do and keeps aloof himself from bad deed. Therefore, man's deed depends on his intention and volition and God does not interfere in the achievement of man's deed (Eyji, 1991, 146). In addition, God cannot be considered as the creator of all man's deeds, because man commits oppression and God is innocent of oppression (Abdul-Jabbar, 2006, 345).

Another reason is that if man is not independent in doing his deeds, man's duty and his afterlife reward and punishment will be inopportune, because in this case, no man deserves praise, blame, reward and punishment for his deeds (Teftazani, 1999, 80).

\subsection{Criticism}

The above-mentioned reasons indicate that man's deed in fact, is referred to himself and he does it voluntarily and freely, but it does not denote man's independency in doing his deed and the negation of the Creation of the deed by God. If these reasons would be trusted and correct, they negates determinism, but negating determinism does not require the correctness of conferment. Conferment is incompatible with monotheism principle in the Creation, because conferment is ditheism and polytheism.

\subsection{Ash'arites' View}

The majority of Ash'arites believe that all man's deeds are achieved only by God's power and man's power and volition is affectless in achieving his deeds to defend monotheism in the Creation and the generality of divine fortuity (Fakhrerazi, 


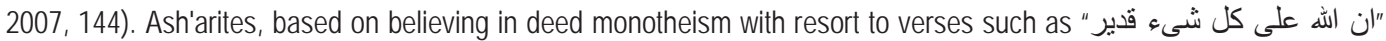

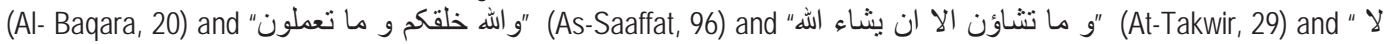

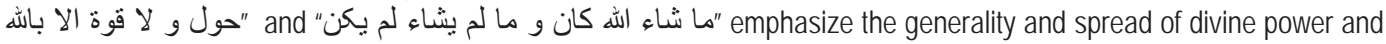
consider all man's possible facts and deeds including faith, blasphemy, obedience and sin are created by God and belong to divine power. They have considered God only effective in the creation of what is different and believe that all the universe is created by God's power and it is His intention and intending bad deeds for God is permissible, except that God is not endowed with bad deeds (Ashari, 1955, 69). Abu Al-Hassan Ashari has regarded all deeds even blasphemy and servants' sins as God's intention (Ibid, 47).

Ash'arites regard God as the creator of all creators and all servants' deeds, at the same time, they consider no deed obligatory for Him (Sioti, 1985, 7). Abu Al-Mali Joyeni says "Only God is the creator of creatures and there is no أفمن يخلق كمن لا يخلق أفلا" creator but Him, our reason for that fact that only God is the creator of all deeds is His statement تذكرون" (An-Nahl, 17). In this holy verse, God eulogizes his nature for creating deeds and in the case of the participation of someone else but Him in creating deeds, this eulogy will be useless.. No deed is obligatory for God and He has gifted it from His generosity and any punishment is the mere justice and what he has made obligatory is obligatory for servants" (Joyeni, 1987, 120-122).

They, based on their thought basis, say "لا مؤثر فى الوجود الا اله". All beings, qualities, deeds and movements are obtained by God's will and all are directly His creatures (Ghazali, 1983, 193) and doers have not creation role and all are His creatures. God first creates means and then causes. Divine tradition is that causes are created following their means (Teftazani, 1999, 84). Therefore, all man's deeds including ugly and beautiful ones are in fact, God's creatures and servants' power has no role in achieving deed. Servants' obedience and sin are all achieved by God's power and will and is the devotee of obedience and for unbelievers, the devotee of sins. They believe the theory of "acquirement" to rectify "duty", "reward", and "punishment" (Fakhrerazi, 1989, 455).

According to Ash'arites, only God is the real creator of all servants' deeds and man has nor role but acquirement in the sense that God creates the deeds by Man. As man's knowledge on evident does not create evident, man's power on his deed is not effective in creating it, but all man's deeds are occurred by divine power (Joyeni, 1987, 87-88). It is right that man have free choice, but his will is affectless in the achievement of his deed and man's volition is simultaneous and coincident with the achievement of deed that they interpret the very coincidence as acquirement and consider it as the license and corrector of reward and punishment of deeds (Fakhrerazi, 2007, 153-154). They say that man's autonomy has no sense but he creates his deeds deliberately (Teftazani, 1973, 152). In other words, God creates man and man acquires these deeds (Ashari, 1994, 221). Man's power and possibility are achieved by God's power and servants are only the place of the occurrence of deed. In other words, God creates feasible deed coincident with their power volition (Eyji, 1991, 145).

Ascribing possibilities to man as deed and acquirement is not inconsistent with appertaining them to God as divine will and creation. God is the real creator, devotee and creator of these deeds and man is the doer and acquirer of them (Al-Juzi, Undated, 123). It is permissible that the one possibility belongs to two different capable ones that one has the power of creation and the other has the power of acquirement (Nesfi, 2012, 295).

\subsection{Criticism}

The Ash'arites' acquirement theory is another interpretation of determinism. If man's power and free will are not effective in the achievement of deed, the issue of afterlife duty, reward and punishment and the principle of divine justice and man's responsibility will not be justifiable.

\subsection{Shiite's View and Refusal of Performing Bad Deeds by God}

As mentioned before, Mu'tazila by referring to some holy verses of the Koran in which deed is related to servants (AnNajm, 39; As-Sajdah, 17; Ar-Rad, 29; Hud, 7; Kahf, 103; Al-Baqara, 79, 215; an-Nisa, 66, 122; At-Tur, 21' Fussilat, 40) believe in absolute conferment in order to negate ascribing bad deeds to God, protect the correctness of duty and the issue of reward and punishment. However, Ash'arites by referring to verses that indicate God's absolute power and monotheism in creation (Anam, 101, 102; At-Talaq, 12; As-Saaffat, 96; Ibrahim, 27; Ar-Rad, 16; Az-Zumar, 62; Al-Furqan, 25, Al-Qamar, 49, Adh-Dahriyat, 30) positions against Jahmi and conferment in order to choose a mediatory trend, but they also became involved in determinism, because they said that man was able in acquirement and his power was not effective in the creation of possibility and any deed is achieved only by God's will and power. God is the absolute owner 
and it is allowable that He do whatever in His possession and because GBD is legitimate not inherent and rational, therefore, whatever God does is good and none of divine deeds are not bad for God (Fakhrerazi, 1992, 118-119).

The saying that Shiite and researchers believe in and is quoted from the Innocent Imams (pbut) is " لا جبر و و لخو "نفويض بل امر بين الامرين" (Saduq, 1992, 29). In this saying, the mediation of the two groups of verses is concluded and states that each creature is consisted of existence and nature. Therefore, one dimension is toward God and the other dimension is toward nature. In addition, each creature is the origin of effect and effect like the origin of effect has two aspects, light and dark aspects. Thus, the light aspect of the effect is referred to "Allah's aspect" in the origin of effect and dark aspect is the effect is referred to "Nature's aspect" in the origin of effect "العالى للعالى و الدانى للانى" (Sabzevari, 1982, 137).

Certainly, other interpretations are presented concerning this theory that they will be mentioned. Many Shiite scholars believe that God's agency in relation to man's is casual and man's agency is direct. In other words, God has granted existence, life, science and power to servants and man can occupy God-given existence capital as they want. On the other hand, because God has given the foundation of deed to servants, man's deed is also ascribed to God. Some other Shiite researchers like Sheikh Mofid and Mulla Sadra and his students believe man's deeds are in fact, is related to both God's obligation and man. As self's deeds are appertained to man's organs and his self (Mulla Sadra, 1988, 377).

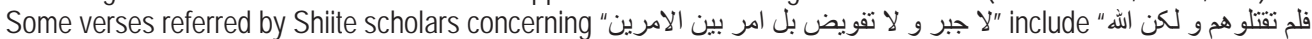
"قتلهم و ما رميت إذ رميت و لكن اله رمى (Al-Anfal, 17), negating and confirming killing enemies by Muslims and shooting by the Prophet is not appropriate unless the mentioned deeds are referred to both God and man and this annuls determinism and conferment. "قاتلو هم يعذبهم الله بأيديكم و يخذهم و ينصركم عليهم " (At-Taubah, 14). God in this holy verse has referred punishing and basing the enemies of religion and Muslims' victory over unbelievers to Himself and believers and this issue cannot be confirmed excepting by comparing the theory of "Between-two Issue. A set of the Koran's verses introduces man as the doer of his works such as "من عمل صالحا فلنفسه و من أساء فعليها" (Fussilat, 46).

Shiite believe that God is powerful over all possibilities, because the cause and criterion of possibility is feasibility and the description of feasibility is common among all the world's possibilities and God's nature is abstract that its relation to all possibilities is equal. Assigning God's power to some possibilities requires preference without a justification that is false (Mofid, 1991, 23). But only good deeds are God's intention and satisfaction. How is it possible that God is satisfied و و ما الله يريد ظلما" "(Ath oppression, oppressor, unbelief, unbeliever, people's hardship and fault? As mentioned in the Koran

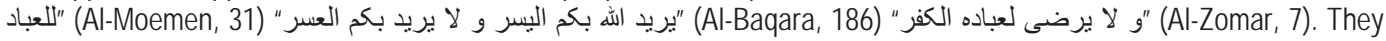

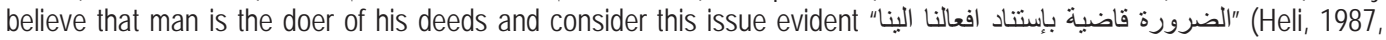
239). God has granted the power of doing works to man and man commits good or bad deeds by choice. The difference is that God is not satisfied with servants' bad deeds and sins (Ibn-Novbakht, 1991, 46-47). The cause of the lack of intending bad deed by God is that intending bad deed is bad and abandoning the intension of good deed is also bad. Therefore, none are not performed by God. Since God is the sage and wise, His wisdom suggests obedience and prevents from sins. Thus, God does not intend bad deeds, but intends obedience. And the other reason is that God has ordered obedience and has forbidden sins. God's order indicates intending obedience and His forbiddance requires hating sins. God's canonized will is ordering obedience and goodness and forbidding sins and badness and His creation will is performing voluntary deed by man (Heli, 2011, 327-8).

Shiite and most of Mu'tazila except Ibrahim Nezam ${ }^{1}$ consider God powerful on performing bad deeds, but they do not ascribe bad deeds to God. They say that performing bad deeds by God in terms of His power is possible and the cause of the lack of bad deeds by God is not His inability, but performing bad deed by God is impossible, because God who is the wise and needless has no motivation to perform bad deed and his knowledge of bad deed prevent from doing that deed and there is no motion and requirement to do that deed (Heli, 1987, 237-8).

Heli concerning the reason of the refusal of abandoning obligation and performing bad deeds by God say that God does not commit bad deeds and does not abandon obligation, because God who is able to perform bad deeds and abandon obligation, is the rejecter of bad deed and the motive of good deed. God is aware of the badness of bad deed and does not need to perform it. The very divine knowledge and independence causes to not perform bad deed by God. The inherent goodness of the deed, which is not corruptive is sufficient to provide the motive to intend good deed (Heli, 2011, 327). Furthermore, the refusal of performing bad deed by God does not destroy God's power, because it is owing to God's wisdom (Ibid, Undated, 133).

\footnotetext{
${ }^{1}$ Nezam Mu'tazila say that God is not able to perform bad deed, because someone who does bad deed is ignorant or needy. While, ignorance and need are incompatible with God's absolute knowledge and wealth. Therefore, performing bad deed by God is inherent impossible (Heli, 1987, 238), but Shiite and most Mu'tazila believe that performing bad deed by God is occurrence refusal not inherent one. God can perform bad deed, but He do not do so, because of His knowledge and wisdom.
} 
Sheikh Toosi with a logical argument from the kind of associative analogy says that God is aware of and powerful over all the details of bad deeds and abandon of obligations and has no need to perform bad deed and abandon obligation and someone who has such a position necessarily is impossible to commit bad deed or abandon obligation. Therefore, God does not perform bad deed and abandon obligation (Toosi, 1999, 127).

In the Koranic teachings, the achievement of deeds are appertained to divine power and divine power is used in three senses including creation, compliance and proclamation and the intention of Ghadr is writing and expression (Fazel Meghdad, 2001, 215).deeds performed by God are all appropriate and satisfactory by God. Servants' bad and good deeds all belong to divine fortuity, but not in the sense that they are created by God (Mofid, 1992, 42). It means that God has proclaimed the reward of good deeds and the punishment of sins. Divine fortuity regarding his servants' deeds is in و قضيناهم الى بنى " the sense of proclamation, writing and expression not creation (Heli, 2000, 90-91). As in the holy verse إسر ائيل فى الكتاب" (Al-Asra, 4), divine fortuity is in the sense of proclamation.

\section{Determinists' Doubts and Their Responses}

Determinists have mentioned various reason to confirm their claim that some of them are analyzed as follows:

1. The criterion of attaching God's power to objects is the possibility and the need to doer. This possibility is common among all possibilities. God's nature is equal in relation to all possibilities. Therefore, God's power is pervasive and encompasses all possibilities (Eyji, Undated, 283). For this purpose, all possibilities including man's nature and his deed should be created and predestined by God (Ibid, 1991, 148).

Criticism: In this reasoning, using the possibility of dominance over objects, all creatures are directly ascribed to God, while, the possibility of dominance over objects indicates that each possibility depend on necessity either directly or indirectly. In referring to the indirect one, the need of possibility is satisfied in the sense that with divine will, man's deed is his creature and indirectly belongs to God's power.

2. If it is asked that why God had intended all events including obedience and disasters? It can be the response that its rational reason is that God is all-powerful on all deeds that servants acquire (Baqlani, Undated, 319320), because God in the Koran say "فعال لما يريد" (Ibid, 295). None of divine deeds is endowed with badness. Badness is a deed that its doer loses something. God does not lose anything by creating blasphemy for some people. Therefore, creating blasphemy is not bad for God, but unbeliever loses by acquiring blasphemy. Thus, acquiring blasphemy for unbeliever is bad (Nesfi, 2012, 306).

Criticism: The criterion of the badness of deed is not unique to doer's loss. God also does not benefit from good deeds, but deeds' benefit and loss refer to creatures themselves.

3. God's previous knowledge of the achievement of servants' deeds makes performing the deeds necessary and what God knows that his servants do not do that, doing that work for servants is impossible, otherwise, God's knowledge will be converted into ignorance. Based on the demand of divine knowledge, performing some deeds by man is necessary and certain and some other impossible. Therefore, there is no place for man's free will (Eyji, 1991, 155).

Criticism: Man's voluntary deed belongs to divine knowledge with the stipulation of free will. God from the beginning, knows that free doers perform their works freely and by choice. Therefore, man's free will is compatible with divine previous knowledge.

4. Servant's deed is achieved by God's power not by servant's power, because monotheism in creation requires that God be the only creator of all things including man's deeds. If it is permissible that servant's deed is achieved by man's power, the assemblage of two effective independent ones in one effect would be necessary that is impossible. In addition, if servants' deed is achieved by their power, abandoning that deed should be possible for them unless committing the deed will be necessary for them that is contrary to the demand of omnipotence. If abandoning that deed is possible like its committing for them, doing the deed and the lack of abandoning it requires preference without a justification, which is impossible (Eyji, 1991, 148).

Criticism: The reality of monotheism in creation is that God is the independent creator who in his creation does not need another creature. Therefore, it is permissible that man would be the origin of creation with God's permission and according to his laws. In other words, man's deed and creation is along God's agency. The assemblage of two different effective ones in one effect is possible along each other. On the other hand, the advisability of deed and God's order to do it is the appropriated and preferable cause of committing deed and the mischief of deed and God's forbiddance is the preferable cause of abandoning that deed. Therefore, man's power on doing and abandoning deed does not require preference without a justification, but the creation of 
motive and motivation in man's self is its preference.

5. Ghadriyeh has supposed that God has conferred man's life affairs to them and man can do whatever he likes by his absolute authority. According to the group's belief, it is necessary that man considers himself needles of God and has no inclination to obey Him (Tabari, 1996, 171).

Criticism: If this reason is supposedly correct, it does not negate absolute conferment and negating absolute conferment does not require the confirmation of determinism.

6. Ash'arites' claim is that according to the holy verse of "الله خالق كل شىء", God creates servants' good and bad deeds. Bad deeds such as servants' blasphemy, oppression and sins are all created by God, but creating badness is not bad and God creates bad deeds not their doer (Teftazani, Undated, 294).

Criticism: Sheikh Abdul-Jalil Razi Ghazvini concerning the refusal of performing bad deeds by God says that the word "all" in the verse "اله خالق كل شیى" is in the sense of some. Any deed that does not decrease divinity from good deeds belongs to God's power and will. Bad deeds do not deserve God. Disgraces, corruption, blasphemy and transgression are not God's intention. Man commits bad deeds due to ignorance and satisfaction of his need, while, God is aware of the badness of all bad deeds and is needless of the bad deeds. Therefore, it is not allowable for Him to intend bad deed (Ghazvini Razi, 1979, 487-9, 495). As Sheikh AbulFutuh Razi following the verse "قل لا أملك لنفسى ضر ا و لا نفعا الا ما شاء اله اله (Yunes, 49) writes that deeds performed by man that some of them are ordered to do, some are forbidden from doing them and some other ones are permissible that God is devotee toward the first group, supervisor to the second group and neither devotee nor supervisor toward the third group.

7. Determinists say that the word "لنشى" in the verse "و لا تقولن لثىء إنى فاعل ذلك غدا الا أن يشاء الله (Kahf, $23,24)$ has generality and includes obedience, sin and permissible deed. Thus, all man's obedience and sins as well as permissible deeds are achieved by God's will and man is forced in all of his deeds.

Criticism: Sheikh Abul-Futuh Razi in rejecting their theory states that the purpose of "أن يشاء الهاء is obedience as Forrah also has mentioned it. In addition, this verse is descended concerning humility and respect and interruption with God and fear as well as forbidding from calling for help to God with sin and impunity. According to the unanimity of believers, it is not permissible for any Muslim to say "God willing, I will commit sin tomorrow". The word "شى" in the above verse does not include sin and sin is not naturally as a satisfactory intention for God (Razi, 1988, 337-8).

Sheikh Abul-Futuh Razi in interpreting several other verses negates determinists' beliefs that we mention some of them as examples:

"و ما جعل الله من بحيرة ..." (Al-Maedah, 103): the verse is concerned with the four camel types that people respected them at the time of Pagan Ignorance. For this purpose, they forged a number of order for them. God in this verse states that these orders are not mine (Tabatabaie, 2011, 156). Sheikh in the interpretation of the verse mentions that this verse explicitly indicates the angulation of determinism. Determinists point out that the doer of the deeds performed by man such as blasphemy, faith, obedience, sin, impunity and badness is in fact, God. In this verse, God stipulate that what unbelievers did, said and put are not said and put by me (Razi, 1996, 175).

"تريدون عرض الدنيا و الله يريد الآخرة" (Al-Anfal, 67) Najar considers God's will inherent and Ash'arites regard God's will as old and according to both sayings, it is necessary that all intentions are His intention (determinists say that our intentions are God's intentions). This verse negates determinists' saying, because God in this verse has separated His will from our will so that has stated that "your will is toward the world namely worldly deed and wealth and my will is afterlife deed of obedience (Razi, 1976, 444).

" (Alو لا تكسب كل نفس الا " Anam, 164). These two verses are the reason of annulling determinism. The firs one

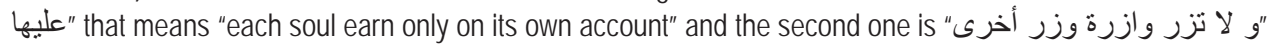
that means "nor doth any laden bear another's load". Another reason also is the correctness of justice religion that is "... that means "then unto your Lord is your return and He will tell you that wherein ye differed". In other words, you are given retribution and reward based on what you did (Razi, 1976, 109).

Some verses of the Koran indicate deed monotheism and some other ones mention man's free will and afterlife reward and punishment. Belonging man's will to deeds along God's will and agency are compatible with deed monotheism. If Ash'arites' quoted reasons are correct, they negates absolute conferment, but do not confirm determinism. Determinism is incompatible with divine wisdom, justice, generosity and benevolence. As 
Imam Reza (pbuh) states "God is not obeyed reluctantly (Sadugh, Undated, 361) and Imam Sadegh (pbuh) mentions "God is more magnanimous than making people obliged to do affairs out of their ability (Tabresi, 2007, 360).

\section{Sanviyeh's Doubt and its Response}

Sanviyeh concerning forms says that the world is full of good and evil things and nothing can be issued from mere goodness but goodness. Therefore, good things are all issued from the Light or God and darkness or Devil is the origin of evilness (Al-Amedi, 2008, 209).

The origin of this belief is incorrect that considered evil as an existence issue contrary to good, while, evil is a nonexistence issue and is contrary to good non-existentially. Evil, which is a non-existence issue does not require origin. Therefore, the universe does not need creator but God and what He creates is good and evilness is abstracted from inadequacies and non-existence and is not a reality by the side of good.

Philosophers believe that divine mercy and generosity are widespread and what divine fortuity is entitled to be in fact, goodness and perfection. Partial worldly and afterlife evilness is accidental. The existence of object, which are inherently good belongs to divine fortuity and any creatures are good for themselves as well as for objects compatible with them. The difference is that if a creature annihilates the nature of other object or its natural perfection, that creature is considered evil in relation to that object (Farabi, 2008, 131).

According to most of theologians, evil does not belong to God's will. As mentioned in Shahrestani's Nahaye AlEqdam, no evil is in God's deeds. Therefore, if evil is found in divine deeds, it is a relative and comparative issue between one object and other object. Evil is ascribed to man's voluntary deeds, which is good by its referring to God and it will be titled as "evil" in terms of its reference to servants' acquirement (Shahrestani, 2013, 152).

Evil inherently refers to non-existence dimensions (lack of nature and absence of nature's perfection) and the evilness of some existence affairs is a relative that is accidental evil not natural evil. Bad deeds and morality are not inherently evil, but they are the perfection of anger and lust strength and accidental evil. These two issues of the existence of lust and anger are accidental forged in terms of non-existence prestige and in terms of their goodness that cause to survive kind and reject contraries are naturally forged (Ibn-Sina, 1981, 320).

\subsection{Compatibility of Bad Deeds and Moral Evil with God's Perfection Qualities such as Justice, Wisdom and Benevolence}

Most theologians believe that God owing to calm suffering people's pains is the guarantor of remedy and will give reward and punishment sufficiently that oppressed people will be satisfied in the afterlife due to their pain in this world. Life calamities and difficulties, which are regarded evil, are in fact, wise and good, however, sometimes we are unaware of their wisdom. God is the guarantor of remedy owing to calmness and giving power to oppressor. In other words, $\mathrm{He}$ pleads for justice in this world or that world (Abdul-Jabbar, 1960, 526).

Moral evil such as malevolence, cruelty and unkindness are among man's free will (Shuri, 30). Man's authority and freedom in choosing affairs are good for him and bring perfection. Sometimes man chooses evil in selecting affairs and commits sin. Therefore, God's revenge and wrath befall him and is entangled among divine pains and punishment and is duly punished for his acts (Al-Araf, 136; Hud, 82; Fil, 4). Since free will is good, the evil, which is the necessity of the free will is achieved. Afterlife evil is the effect of man's blasphemy and sin on the earth (Mulla Sadra, 2010, 248).

\section{Conclusion}

Ash'arites to defend deed monotheism, ignored divine justice and followed determinism. In addition, Mafvaze defended God's justice and questioned deed monotheism, but Shiite expound man's free will in light of divine agency by suggesting the theory of "أمر بين الأمرين", which is maintaining both deed monotheism and divine justice.

It is the plausibility of the vast majority of Shiite theologians that by believing in God's omnipotence of all deeds, divests performing bad deeds and abandoning obligation from God and considers man's bad deeds as the ones, which are not God's intention and God is not satisfied with them.

Man's bad deeds have two dimensions, existence dimension and non-existence one. Each deed is ascribed to God from its existence dimensions in the hierarchy of causes, because non-divine are all subjugated doers with the difference that such deeds are not God's intention and He is not satisfied with them owing to their non-existence dimension that destroy human perfection so that God has forbidden them and someone who commits bad deeds has 
committed sin that makes him/her deserved to reproach and divine punishment.

It is correct that all deeds are encompassed by divine eternal power, but they are natural intention in terms of their goodness and are accidental intention in terms of their evilness. Natural evil is non-existence affairs without needing origin, therefore, they do not belong to divine fortuity, but accidental evil that are few and existence affairs are accidental demand.

No disaster is not achieved without divine wisdom and goodness. In the case of evil, philosophers mostly believe in the minimum of evil or its non-existence, but most theologians believe in the existence of evil. According to Islamic theologians and philosophers, the existence of evils in the world is completely justifiable and it does not hurt God's wisdom.

\section{References}

The Koran, translated by Alahi Ghomsheyi

Amadi, H. (2008). Khaya Al-Maram Fi Elm Al-Kalam, Research by Ahmad Abdul'Rahim Al-Sayah, Cairo, Maktab Al-Saqafah Al-Diniya. Ibn-Sina, H. (1981). Al-Isharat wa'I-Tanbihat, Described by Khajeh Nasir Al-din Toosi, Tehran, Daftare Nashre Ketab.

Al-Juzi, I. Q. \& Bin Abi-Bakr, M. (Undated). Shafa Al-Alil Fi Masael Al-Qaza Wa Al-Qadar Wa Al-Hekamah Wa Al-Talil, Taliq Abu Mazn Al-Mesri \& Kamal Saeid Fahmi, Maktaba Al-Tavfiqa.

Ibn-Navbakht, A. E. (1991). Al-Yaqut Fi Elm Al-Kalam, Research by Ali Akbar Ziayi, Qom, Maktab Ayatollah Al-Ozma Al-Marashi AlNajafi.

Ash'ari, A. (1994). Maqalat Al-Eslamin Wa Akhtelaf Al-Moslin, Research by Mohammad Mehi Al-din Abdul-Hamid, Beirut, Al-Maktaba alMisriya Lelteba Wa Nashr.

Ibid. (1955). Al-Limah Fi Raddi Ala Ahli Zeikh Wa Badh, Corrected by Hamoda Kharabah, Cairo, Sherka Mosahema Al-Misriya.

Ibid. (1991). Al-Mavaghefo Sharha, Explained by Ali Bin Mohammad Gorgani, Qom, Manshurat Al-Sharif Arzi.

Baghlani, M. (Undated). Tamhid Al-Avael Wa Talkhis Al-Dalael. Cairo, Maktaba Al-Mostafa.

Teftazani, M. (1999). Sharh Al-Aqayed Al-Nasfiya (Najm Al-din Nesfi Samarghandi), Research by Taha Abdul-Rauf Saed, Cairo, AlMaktaba Al-Azhariya Leltoras.

Ibid. (Undated). Sharh Al-Maghased, Research by Abdul-Rahman Amire, Qom, Manshurat Al-Sharif Arzi.

Ibid. (1973). Sharh Al-Aqayed Al-Mohshi, Lithographic Print, Mahabad, Seyedian.

Joyeni, A. (1994). Al-Ershad Ela Ghvateh Al-Adele Fi Aval Al-Eteghad, Research by Zakariya Amriyat, Beirut, Dar Al-Kotob Al-Elmiya.

Ibid. (1987). Lema Al-Adele Fi Qavaed Ahl Al-Sona Wa Al-Jima, Research by Favqia Hussein Mahmood, Beirut, Alam Al-Kotob.

Heli, H. (1981). Kashf Al-Favaed Fi Sharh Ghavaed Al-Aqayed, Lithographic Print, Tabriz, Maktabe Islam.

Ibid. (1987). Kashf Al-Morad Fi Sharh Tajiid Al-Eteqad, Qom, Matboate Dini Institute.

Ibid. (Undated). Manahej Al-Yagin Fi Osul Al-Din, Research by Mohammad Reza Anasir Qomi, Qom, Bustane Ketab.

Ibid. (Undated). Nahaya Al-Vesol Ela Elm Al-Osul, Research by Ebrahim Bahadori, Qom, Imam Sadegh (pbuh) Institute.

Razi, H. (2536 Imperial Government), Tafsir Ravhi Al-Jenan Va Rohe Al-Janan, Corrected by Abu Al-Hassan Sherani and Ali Akbar Ghofrani, Tehran, Islamiye Bookstore.

Ibid. (1988). Ravz al-Jenan Va Roh Al-Janan Fi Tafsir Al-Qoran, Corrected by Mohammad Jafar Yahaqi and Mohammad Mehdi Naseh, First Edition, Mashhad, Astane Ghodse Razavi Publications.

Ibid. (1996). Ravz al-Jenan Va Roh Al-Janan Fi Tafsir Al-Qoran, Corrected by Mohammad Jafar Yahaqi and Mohammad Mehdi Naseh, Mashhad, Astane Ghodse Razavi Publications.

Sabzevari, M. H. (1982). Asrare Al-Hokm, With an Introduction by Toshihiko Izotesu, by H. M. Farzad, Tehran, Moli Publications.

Sioti, J. (1985). Etmam Al-Deraya Leqara Al-Naqaya, Taliqat Al-Sheikh Ebrahim Al-Ojoz, Beirut, Dar Al-Kotob Al-Elmiye.

Shahrestani, M. (Undated). Al-Melal Wa Al-Nahl, Research by Mohammad Seyyed Gilani, Beirut, Dar Al-Marafa.

Sadugh, M. (1992). Al-Eteghadat, Research by Esam Abdul Saied, Qom, International Congress of Sheikh Mofid.

Ibid. (Undated). Al-Tavhid, Research by Seyyed Hashem Husseini Tehrani, Qom, Moasasa Al-Nashr Al-Islamiya Lejama al-Modaresin.

Tabatabaie, M. H. (1968). Al-Mizan Fi Tafsir Al-Quran, Beirut, Moasasa Al-Elmi Lel-Matbuat.

Al-Tebresi, A. (2007). Al-Ehteyaj, Beirut, Dar-Morteza.

Tabari, M. (1996). Al-Tabsir Fi Ma'alem Al-din, Research by Ali Ibn Abdul-Aziz, Riyadh, Dar Al-Asma.

Toosi, M. (1999). Al-Anvar Al-Jalaliyah Fi Sharh Al-Fosul Al-Nasiriya, Described by Fazel Meghdad Siori, Research by Ali Hajiabadi, Mashhad, Majma Al-Bohoth al-Islamiyah.

Ibid. (Undated), Qavaed Al-Qayed, Appendices by Jafar Sobhani Tabrizi, Qom, Imam Sadegh (pbuh) Institute.

Ghazali, M. (1983). Ghavaed Al-Aqayed, Research by Mosa Mohammad Ali, Beirut, Alam Al-Kotob.

Farabi, A. (2008). Farabi's Philosophical theses, Tr. By Saeid Rahimian, Tehran, Entesharat Elmi Farhangi Company.

Ibid. (2001). Al-Levameh Al-Elahiya Fi Al-Mabaheth Al-Kalamiya, Research by Seyyed Mohammad Ali Ghazi, Qom, Boostan Ketab.

Fakhrerazi, M. (1986). Al-Arbaein Fi Osul Al-din, Research by Ahmad Hejazi Alseqa, Cairo, Maktaba Al-Koliyat Al-Azhariyah.

Ibid. (2007). Al-Ishara Fi Elm Al-Kalam, Research by Hani Mohammad Hetmad Mohammad, Cairo, Al-Maktaba Al-Azhariya Leltorath.

Ibid. (1989). Ketab Al-Mohsel, Mohasal Afkar Al-Motaghademin Wa Al-Mota'akharin Men Al-Olama Wa Al-Hokama Wa Al-Motakalamin,

Research by Hussein Atay, Cairo, Maktab Dar Al-Torath.

Ghazi Abdul-Jabbar, A. (2006). Sharh Al-Osul Al-Khamsa, Research \& Introduction by Abdul-Karim Osman, Cairo, Maktaba Vahabe. 
Ibid. (Undated). Al-Mokhtasar Fi Osul Al-din, Cairo, Maktab Al-Mostafa.

Ibid. (2003). Al-Mokhni Fi Abvab Al-Tavhid Wa Al-Adl, Research by Abul-Ala Afifi, Cairo, Dar Al-Kotob Al-Misriya.

Ghazvini Razi, A. (1979). Naghs, corrected by Jalal Al-din Mohades Armoy, Tehran, Association of National Works.

Lahiji, M. (1992), Mafatih Al-Ejaz Fi Sharhi Golshan Raz, Corrected by Mohammad Reza Barzegar Khaleqi and Effat Karbasi, Tehran, Zevar Publications.

Lahiji, M. A. (2004). Gavhare Morad, corrected by Imam Reza (pbuh) Research institute, Tehran, Sayeh Publications.

Mohegh Heli, J. (2000). Al-Moslek Fi Osul Al-din, Research by Reza Ostadi, Mashhad, Majma Al-bohoth Al-Islamiyah.

Mofid, M. (1992). Tashih Eteghadat Al-Imami, Research by Hussein Dargahi, Qom, International Congress of Sheikh Mofid.

Mulla Sadra, M. (1988). Al-Hekmat Al-Motalia fi Al-Asfar Al-Aqliya Al-Arba'a, Beirut, Dar Ahya Al-torath Al-Arabi.

Ibid. (1991). Al-Nokt Al-Eteghadiyah, Research by Reza Mokhtari, Qom, International Congress of Sheikh Mofid.

Ibid. (2010). Philosophical theses, Corrected and Research by Researchers Group, Supervised by Ayatollah Seyyed Mohammad Khamenei, Tehran, Hekmat Islami Sadra Foundation.

Nesfi, A. (2012). Sharh Al-Omda Fi Aqida Ahl Al-Sunna Wa Jama, (Al-Mosami Bel-Etmad Fi Al-Eteqad Li Abi Al-Barakat Al-Nasfi, Research by Abdullah Mohammad Ismail, Cairo, Al-Maktaba Al-Azhariyah Leltorath. 